\title{
Analisis Perbedaan Kinerja Saham Perusahaan Berdasarkan Model Sharpe, Treynor, Jensen dan Sortino Pada Kelompok Saham LQ 45 Di Bursa Efek Indonesia Periode 2010 - 2018
}

\author{
${ }^{1}$ Pantun Bukit, ${ }^{2}$ Yunan Surono, ${ }^{3}$ Nani Astriana \\ ${ }^{1}$ Dosen Fakultas Ekonomi, Universitas Batanghari Jambi, Indonesia. \\ ${ }^{2}$ Dosen Fakultas Ekonomi, Universitas Batanghari Jambi, Indonesia. \\ ${ }^{3}$ Mahasiswa Magister Manajemen Universitas Batanghari Jambi, Indonesia.
}

\begin{abstract}
The research aims to prove the difference in stock performance of LQ 45 stock group companies in the Indonesia Stock Exchange period 2010 - 2018 based on the models Sharpe, Treynor, Jensen and Sortino, and to get a group of stocks that have the most performance well based on the four models. In this research the samples used were the LQ 45 stock group in the Indonesia Stock Exchange from 2010 - 2018 which always emerged as the LQ 45 index counter of as many as 21 issuers, which provided complete data from financial statements, not including banking stocks because it has different financial statements, does not do stock split and does not have a negative book equity. This form of research is an explolanatoris research. The results showed that based on the value of figures with Sharpe model in the range-15.92764 to the maximum range of 25.85580. For model number values with model Treynor in the range-0.22986 to the maximum range of 0.37314. The value of the Jensen model number in the range-0.08787 to the maximum range is 0.33096., while the number value with the Sortino model at the range5.86684 to the maximum range of 9.52381. Based on the measurement of the performance of groups with the Sharpe model has a minimal performance score with Z-score-2.88024 which occurred in July of 2013., while the maximum performance score with Zscore 4.36889 happened in August of 2018. The Treynor model has a minimal performance score with Z-score - 2.88024 that occurred in July of 2013., while the maximum performance score with Z-score 4.36889 occurred in August of 2018. On the Jensen model had a minimal performance score with Z-score-1.99550 which occurred in July of 2013., while the maximum performance score with Z-score 7.30738 occurred in August of 2018. On the Sortino model had a minimal performance score with Z-score2.88024 which took place in July of 2013., while the maximum performance score with Z-score 4.36889 occurred in August of 2018. The results of the test with Kruskal Wallish test on the four models acquired $\chi 2=4.267$, with a probability of 0.118 . Then it can be known that the probability of testing $>0.05$ and $\chi^{2}$ count $<\chi^{2}$ table 5.32. These results showed that there was no significant difference between testing with models of Sharpe, Treynor, Jensen and Sortino. Thus the nil hypothesis (H0) In this study was received. Another test by comparing the calculation of the stock group performance calculations as a continuation of the Kruskal Wallish test was obtained there is no meaningful difference between each treatment by looking at the difference to the four mean rank, which demonstrates consistency in the interdistinction between the four measurements.
\end{abstract}

Keywords: performance group stock, Sharpe model, Treynor model, Jensen model, Sortino model.

\section{PENDAHULUAN}

Pasar modal merupakan suatu pasar untuk berbagai instrumen keuangan (sekuritas) jangka panjang yang bisa diperjualbelikan baik dalam bentuk hutang ataupun modal sendiri, baik yang diterbitkan oleh pemerintah, public authorities maupun perusahaan swasta. Pasar modal memberikan kesempatan pada pihak pengusaha untuk memperoleh dana segar melalui go public, sedangkan investor memiliki kesempatan untuk turut serta memiliki perusahaan dengan membeli saham. Markowitz (1952), menyarankan bagi para investor dalam melakukan suatu investasi, investor sebaiknya tidak menempatkan investasinya hanya pada satu jenis media investasi saja. Para investor secara rasional akan mencari portofolio yang memberikan pengembalian maksimal dengan risiko seminimal mungkin. Instrument keuangan dimaksud meliputi saham, obligasi, valas, deposito, indeks harga saham, produk derivatif lainnya (Samsul, 2006). Portofolio dikategorikan efisien apabila memiliki tingkat risiko yang sama, mampu memberikan tingkat keuntungan yang lebih tinggi, atau mampu menghasilkan tingkat keuntungan yang sama, tetapi dengan risiko yang lebih rendah. Elton dan Gruber (1977). Sedangkan portofolio optimal merupakan portofolio yang dipilih seorang investor dari sekian banyak pilihan yang ada pada kumpulan portofolio yang efisien (Tandelilin, 2001). Peneliti akan mencoba untuk menggunakan 4 parameter yang dapat digunakan untuk mengukur kinerja portofolio yang dikembangkan oleh William Sharpe, Jack Treynor, Michael Jensen dan Sortino. Keempat pengukuran kinerja ini dinamakan pengukuran dengan menggunakan model Sharpe, model Treynor, model Jensen yang tergolong sebagai modern portofolio theory (MPT) dan model Sortino yang merupakan post-modern portofolio theory. Sortino (1980), memperkenalkan suatu rasio baru. Rasio ini menghitung excess return 
portofolio dari Minimum Acceptable Return (MAR) untuk setiap downside deviation. Rasio ini kemudian dikenal dengan nama Sortino ratio.

Beberapa penelitian yang pernah dilakukan sebelumnya, mengenai pengukuran kinerja portofolio menggunakan metode Sharpe, Treynor dan Jensen. Salah satunya, penelitian yang dilakukan oleh Jobson dan Korkie (1981), menunjukkan hasil bahwa Sharpe dan Jensen menunjukkan kinerja yang baik pada data bulanan dan sampel yang kecil sedangkan Treynor tidak menunjukkan kinerja yang baik pada sampel yang kecil dengan menggunakan alat analisis t-test. Penelitian lain juga dilakukan oleh Fadlul Fitri (2002), menggunakan Metode Sharpe, Jensen dan Treynor dengan kendall coeficient menghasilkan bahwa nilai ratarata keseluruhan untuk RVAR, RVOL dan ALPHA dari portofolio yang terdiri dari saham saham beragam industri yang tidak termasuk ke dalam Indeks LQ45, sehingga saham yang layak untuk diinvestasikan adalah saham-saham Indeks LQ45. Hasil statistik adalah beta dan uji konsitensi menunjukkan nilai statistik W signifikan. Portofolio optimal dengan menggunakan Metode Sharpe, Jensen, dan Treynor dengan Z-Score Suryawan (2003), menunjukkan pengukuran kinerja portofolio dengan metode Sharpe, Jensen, dan Treynor akan memiliki karakteristik angka indeks yang berbeda satu sama lain, sehingga tidak dapat dibandingkan satu sama lainnya secara langsung sehingga diperlukan standarisasi ukuran kinerja. Simforianus dan Hutagaol (2008), melihat posisi Reksa Dana yang tergolong superior dan ada tidaknya konsistensi kinerja Reksa Dana tersebut.

Sulistyorini (2009), dalam penelitian tersebut melakukan analisis kinerja portofolio saham LQ45 menggunakan metode Sharpe, Treynor dan Jensen. Perhitungan kinerja portofolio saham dalam penelitian menggunakan uji beda dengan menggunakan One Way of Variance by Rank dengan Kruskal-Wallish, yang sebelumnya dilakukan transformasi data untuk menstandarkan ukuran kinerja tersebut yaitu dengan menggunakan transformasi Z-score (standardized). Dengan melihat selisih ketiga mean rank maka metode Treynor adalah yang paling menunjukkan konsistensi terhadap ketidakbedaan antar ketiga pengukuran, karena Treynor memilik selisih mean rank yang paling rendah terhadap Sharpe maupun Jensen.

Tehrani (2011) mengenalisis kinerja portofolio dari perusahaan investasi yang terdaftar di Bursa Efek Tehran pada periode 2006 - 2010 dengan menggunakan metode Sharpe, Treynor dan Sortino. Hasil pengujian data dengan menggunakan uji statistik Kolmogorov-Smirnov dan Shapiro-Wilk menunjukkan bahwa distribusi data tidak normal. Akhirnya peneliti menggunakan uji non-parametrik untuk menguji hipotesis. Dan dengan menggunakan uji Freidman dan Wilcoxon, hasilnya menunjukkan bahwa ketiga metode tersebut memiliki kontrol yang lebih baik untuk risiko sistematis daripada komponen lainnya. Ataie (2012) mengevaluasi kinerja perusahaan perusahaan dengan menggunakan model Sortino, EROV dan M3. Penelitian ini menggunakan data dari tahun 2006 sampai dengan 2010 dengan menggunakan 42 sampel perusahaan. Dimana peneliti menginginkan apakah terdapat perbedaan hasil kinerja dari ketiga model tersebut, dan membandingkannya dengan kinerja pasar apakah lebih baik atau tidak. Penelitian ini menggunakan pengukuran kinerja dengan model Sortino, EROV dan M3 dan menggunakan metode statistik ANOVA dengan Tukey Test. Peneliti menemukan bahwa kinerja perusahaan perusahaan ternyata berbeda, dan hasil perhitungan dengan metode rasio EROV terbukti signifikan dan lebih besar dibandingkan dengan hasil dari metode Sortino dan M3. Lina Meytasari (2013), penelitian tersebut untuk mengevaluasi kinerja Reksa Dana Saham yang terdaftar di BAPEPAM Indonesia dengan model EROV, Sortino dan Sharpe. Penelitian ini menggunakan Reksa Dana Saham yang aktif dari tahun 2008 sampai tahun 2012. Data yang digunakan dalam penelitian ini merupakan data sekunder yang didapatkan dari 30 sampel Reksa Dana Saham. Pada penelitian ini, dengan menggunakan model Sharpe, model Treynor, model Jensen dan model Sortino mengasumsikan adanya hubungan linear antara pengembalian (return) portofolio dengan pengembalian dari index pasar. Keempat model tersebut mendasarkan analisisnya pada return masa lalu untuk memprediksikan return dan risiko masa datang.

Teori keuangan menjelaskan bahwa bila risiko investasi meningkat maka tingkat keuntungan yang disyaratkan investor semakin besar. Return dan risiko mempunyai hubungan yang serarah dan linear, atau yang sering dikenal dengan high risk high return, yang artinya semakin besar risiko yang harus ditanggung, semakin besar pula return yang dihasilkan. Bursa Efek Indonesia (BEI) memiliki sekelompok saham yang mempunyai likuiditas tinggi, kapitalisasi pasar yang besar, memiliki prospek pertumbuhan, memiliki frekuensi perdagangan tinggi, serta kondisi keuangan yang cukup baik, tidak fluktuatif dan secara obyektif telah diseleksi oleh BEI, dan merupakan saham yang aman dimiliki karena fundamental kinerja saham 
tersebut bagus, dan paling banyak diminati oleh para investor, sehingga dari sisi risiko kelompok saham LQ 45 memiliki risiko terendah dibandingkan saham-saham lain.

\section{Landasan Teori \\ Kinerja Portofolio}

Markowitz berasumsi bahwa preferensi investor hanya didasarkan pada return ekspektasi yang diinginkan (mean) dan besarnya risiko (variance) portofolio yang dapat ditoleransi oleh investor tanpa mempertimbangkan aktiva bebas risiko (risk free asset) sehingga model ini disebut juga dengan mean variance model. Perkembangan konsep pengukuran kinerja portofolio terjadi pada tahun 60-an yang dipelopori oleh Wiliam Sharpe, Treynor, dan Michael Jensen. Konsep ini berdasarkan teori Capital Market. Ketiga ukuran ini dikenal dengan istilah composite (risk-adjusted) measure of portofolio performance karena mengkombinasikan antara return dan risk dalam suatu perhitungan (Jogiyanto, 2003).

\section{Model Sharpe.}

Kinerja portofolio dengan menggunakan konsep dari Garis Pasar Modal / Capital Market Line (CML) atau lebih dikenal dengan istilah Reward to Variability Ratio (RVAR). Dimana Sharpe menyatakan series kinerja portofolio dihitung merupakan hasil bersih dari portofolio dengan tingkat bunga bebas risiko per unit risiko dengan diberi simbol Sp. Indeks kinerja Sharpe dihitung dengan rumus berikut (Manurung, 2000):

$S p=\frac{R p-R f}{\sigma p}$

Dimana; $\mathrm{Sp}=$ indeks kinerja Sharpe; $\mathrm{Rp}=$ return portofolio atau tingkat pengembalian pasar; $\mathrm{Rf}=$ return bebas risiko tingkat bunga bebas risiko.; $\sigma p=$ total risiko yaitu hasil jumlah dari risiko sistematik dan risiko unsistematik.

Portofolio sama dengan portofolio pasar maka total risiko sama dengan risiko sistematis atau risiko pasar atau dapat disebut dengan beta.

\section{Model Treynor.}

Treynor mengansumsikan bahwa portofolio sangat diversifikasi dikenal dengan istilah Reward to Valatility Ratio (RVOR). Oleh karenanya indeks Treynor menyatakan series kinerja portofolio dihitung merupakan hasil bersih dari portofolio dengan tingkat suku bunga bebas risiko per unit risiko pasar portofolio tersebut dengan diberi simbol Tp. Indeks kinerja Treynor dihitung dengan formula berikut (Manurung, 2000):

$T p=\frac{R p-R f}{\beta p}$

Dimana; $\mathrm{Tp}=$ indeks kinerja Treynor; $\mathrm{Rp}=$ return portofolio atau tingkat pengembalian pasar; $\mathrm{Rf}=$ return bebas risiko tingkat bunga bebas risiko; $\beta p=$ Risiko pasar dari portofolio atau risiko sistematik portofolio.

Dalam menghitung indeks Treynor ini maka asumsi yang harus diperhatikan bahwa hasilnya memberikan evaluasi pada satu periode, karena tingkat pengembalian portofolio dan risiko membutuhkan periode yang panjang. Bila periode yang dipergunakan cukup pendek maka risiko yang dihitung dengan beta memberikan hasil yang tidak wajar atau tidak representatif.

\section{Model Jensen.}

Jensen sangat memperhatikan CAPM dalam mengukur kinerja portofolio tersebut yang sering disebut dengan Jensen ALPHA (Differential Return Measure). Jensen ALPHA merupakan sebuah ukuran absolut yang mengestimasikan tingkat pengembalian konstan selama periode investasi dimana memperoleh tingkat Jensen ALPHA pengembalian diatas (dibawah) dari buy-hold strategy dengan risiko sistematik yang sama. Adapun formula Jensen ALPHA sebagai berikut (Manurung, 2000):

ap $=R_{p}-\left[R_{f}+b_{p}\left(R_{m}-R_{f}\right)\right]$

Dimana; ap = Indeks Jensen; $\mathrm{Rp}=$ return portofolio atau tingkat pengembalian pasar; $\mathrm{Rf}=$ return bebas risiko tingkat bunga bebas risiko; bp = koeffisien beta pasar 
Pantun Bukit et al, Analisis Perbedaan Kinerja Saham Perusahaan Berdasarkan Model Sharpe, Treynor, Jensen dan Sortino Pada Kelompok Saham LQ 45 Di Bursa Efek Indonesia Periode 2010 - 2018

Semakin tinggi ap yang positif maka kinerja portofolionya semakin baik.

\section{Model Sortino.}

Pada awal tahun 1980, Sortino memperkenalkan suatu rasio baru. Rasio ini menghitung excess return portofolio dari Minimum Acceptable Return (MAR) untuk setiap downside deviation. Rasio ini kemudian dikenal dengan nama Sortino ratio. Tingkat suku bunga Sertifikat Bank Indonesia digunakan sebagai tingkat suku bunga bebas risiko. Besarnya Minimal Acceptable Return (MAR) adalah tingkat suku bunga minimum yang diharapkan sebagai return oleh setiap investor dari investasi yang dilakukannya. Return yang berada dibawah MAR maka akan dianggap sebagai return yang tidak menguntungkan atau risiko dan return yang lebih besar dari MAR akan dikatakan sebagai return yang menguntungkan (Simforianus dan Hutagaol, 2008). Metode ini hampir serupa dengan pengukuran yang dilakukan oleh metode Sharpe dengan dua perbedaan utama yaitu imbal hasil aset bebas risiko diganti dengan imbal hasil minimum yang diharapkan dan standar deviasi yang digunakan hanya standar deviasi dari imbal hasil portofolio yang berada dibawah imbal hasil minimum yang ditetapkan dimana dalam penelitian ini hasil minimum yang ditetapkan berasal dari nilai suku bunga Bank Indonesia. Adapun formula perhitungan yang digunakan adalah:

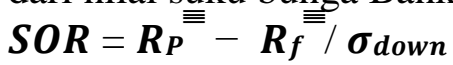

Dimana: Rp = Rata-rata return portofolio Reksa Dana; Rf = Suku bunga bebas risiko yang ditetapkan sebagai MAR; $\sigma_{\text {down }}=$ Downside deviation

Menurut Chaudry dan Johnson (2008) adapun downside deviation (DD) sendiri dapat dihitung dengan formula berikut:

$D D^{2}=\frac{1}{N} \sum_{t=1}^{N}(R p t-M A R)$

Dimana: $\mathrm{Rpt}=$ Return portofolio pada periode $\mathrm{t},(\mathrm{Rpt} \leq \mathrm{MAR}) ; \mathrm{MAR}=$ Minimum Acceptable Return, yakni suku bunga bebas risiko (BI rate);

Dengan syarat (Simforianus, dkk, 2008): jika (Rp - MAR) negatif, maka digunakan (Rp - MAR); jika (Rp MAR) positif, maka digunakan angka 0

\section{HASIL}

\section{Analisis Kinerja Kelompok Saham berdasarkan Model Sharpe}

Pengukuran menggunakan model Sharpe atau juga disebut sebagai Reward to Variability Ratio (RVAR) menekankan pada risiko total atau deviasi standar. Deviasi standar menunjukkan besar kecilnya perubahan return suatu saham terhadap return rata rata saham yang bersangkutan. Untuk kepentingan memprediksi kinerja masa datang digunakan data masa lalu. Return rata-rata masa lalu dianggap sebagai return prediksi masa datang dan deviasi standar return masa lalu dianggap sebagai prediksi risiko masa datang. Untuk menganalisis kinerja menggunakan model Sharpe dibutuhkan data seperti avarage return, deviasi standar, dan risk free rate. Hasil dari perhitungan kinerja saham dari ke-17 kelompok saham LQ 45 dengan model Sharpe untuk masing-masing periode, dimana warna kuning merupakan bulan dimana mempunyai nilai negatif.

Tabel.1

Kinerja Saham berdasarkan Model Sharpe kelompok saham LQ 45 periode 2010 - 2018.

\begin{tabular}{|c|c|c|c|c|c|c|c|c|c|c|}
\hline \multicolumn{11}{|c|}{ Model Sharpe } \\
\hline & Bulan/ Tahun & 2010 & 2011 & 2012 & 2013 & 2014 & 2015 & 2016 & 2017 & 2018 \\
\hline 1 & Januari & & $-8,9425$ & 3,6016 & 1,2276 & $-0,0728$ & $-0,8570$ & 4,6086 & $-2,1267$ & 7,4177 \\
\hline 2 & Februari & $-0,5229$ & $-4,9277$ & 5,4756 & 2,9579 & 4,7388 & 3,6873 & 5,3546 & 2,2432 & $-1,7268$ \\
\hline 3 & Maret & 6,2286 & 4,3522 & 5,5579 & 0,7874 & 4,1109 & $-0,3638$ & 8,6873 & 1,1450 & $-8,6577$ \\
\hline 4 & April & 1,4654 & 3,5240 & $-2,0356$ & 2,5420 & 4,4159 & $-7,8082$ & $-0,1617$ & 0,5222 & $-1,1017$ \\
\hline 5 & Mei & $-4,7813$ & 0,1486 & $-7,0119$ & 0,2301 & 0,3367 & 5,1222 & $-3,8792$ & $-0,1180$ & $-10,3904$ \\
\hline 6 & Juni & 3,4011 & 0,7518 & $-2,5905$ & $-6,7435$ & 0,1894 & $-6,2691$ & 8,3845 & 1,0730 & $-13,9608$ \\
\hline 7 & Juli & 5,6044 & 3,1860 & 5,0888 & $-15,9276$ & 4,2375 & $-6,2951$ & 8,5403 & 3,6072 & 3,1421 \\
\hline 8 & Agustus & 0,3927 & $-4,8898$ & $-2,6334$ & $-0,3554$ & $-0,4882$ & $-8,0427$ & 18,8268 & 5,9718 & 25,8558 \\
\hline 9 & September & 8,8926 & $-6,9169$ & 6,0579 & $-8,6943$ & $-2,3249$ & $-0,9317$ & 2,7296 & 0,9908 & $-3,7606$ \\
\hline 10 & Oktober & 3,8124 & 9,7154 & $-3,5959$ & 1,9917 & 0,2031 & 6,3687 & 6,7727 & 3,9422 & $-3,6135$ \\
\hline 11 & November & $-2,0117$ & 5,9974 & $-3,5702$ & $-1,6361$ & $-0,6377$ & $-4,8612$ & $-2,2244$ & $-4,3721$ & $-3,6544$ \\
\hline 12 & Desember & 3,9358 & 2,5383 & 3,7621 & $-1,1252$ & $-0,9692$ & 1,4799 & 0,6435 & $-0,2425$ & 2,3503 \\
\hline
\end{tabular}

Sumber; data olahan, 2019 


\section{Analisis Kinerja Kelompok Saham berdasarkan Model Treynor.}

Model Treynor atau sering disebut sebagai Reward to Valatility Ratio (RVOR), menggunakan return rata-rata masa lalu sebagai expected return dan juga beta sebagai tolak ukur risiko. Beta menunjukkan besar kecilnya perubahan return suatu kelompok saham terhadap perubahan market return. Sebagai tolak ukur risiko investasi digunakan beta karena pada umumnya fluktuasi harga saham dipengaruhi oleh fluktuasi pasar. Suatu sekuritas yang mempunyai beta $<1$ dikatakan berisiko lebih kecil dari risiko kelompok pasar. Sebaliknya suatu sekuritas yang mempunyai nilai beta $>1$ dikatakan mempunyai risiko sistematik yang lebih besar dari risiko pasar.

Tabel 2

Kinerja Kelompok Saham berdasarkan Model Treynor saham LQ 45 periode 2010 - 2018.

\begin{tabular}{|c|c|c|c|c|c|c|c|c|c|c|}
\hline \multicolumn{11}{|c|}{ Model Treynor } \\
\hline & Bulan/ Tahun & 2010 & 2011 & 2012 & 2013 & 2014 & 2015 & 2016 & 2017 & 2018 \\
\hline 1 & Januari & & $-0,1291$ & 0,0520 & 0,0177 & $-0,0011$ & $-0,0124$ & 0,0665 & $-0,0307$ & 0,1070 \\
\hline 2 & Februari & $-0,0075$ & $-0,0711$ & 0,0790 & 0,0427 & 0,0684 & 0,0532 & 0,0773 & 0,0324 & $-0,0249$ \\
\hline 3 & Maret & 0,0899 & 0,0628 & 0,0802 & 0,0114 & 0,0593 & $-0,0053$ & 0,1254 & 0,0165 & $-0,1249$ \\
\hline 4 & April & 0,0211 & 0,0509 & $-0,0294$ & 0,0367 & 0,0637 & $-0,1127$ & $-0,0023$ & 0,0075 & $-0,0159$ \\
\hline 5 & Mei & $-0,0690$ & 0,0021 & $-0,1012$ & 0,0033 & 0,0049 & 0,0739 & $-0,0560$ & $-0,0017$ & $-0,1499$ \\
\hline 6 & \begin{tabular}{|l|} 
Juni \\
\end{tabular} & 0,0491 & 0,0108 & $-0,0374$ & $-0,0973$ & 0,0027 & $-0,0905$ & 0,1210 & 0,0155 & $-0,2015$ \\
\hline 7 & Juli & 0,0809 & 0,0460 & 0,0734 & $-0,2299$ & 0,0612 & $-0,0908$ & 0,1232 & 0,0521 & 0,0453 \\
\hline 8 & Agustus & 0,0057 & $-0,0706$ & $-0,0380$ & $-0,0051$ & $-0,0070$ & $-0,1161$ & 0,2717 & 0,0862 & 0,3731 \\
\hline 9 & September & 0,1283 & $-0,0998$ & & $-0,1255$ & $-0,0336$ & $-0,0134$ & 0,0394 & 0,0143 & $-0,0543$ \\
\hline 10 & Oktober & 0,0550 & 0,1402 & $-0,0519$ & 0,0287 & 0,0029 & 0,0919 & 0,0977 & 0,0569 & $-0,0521$ \\
\hline 11 & November & $-0,0290$ & 0,0866 & $-0,0515$ & $-0,0236$ & $-0,0092$ & $-0,0702$ & $-0,0321$ & $-0,0631$ & $-0,0527$ \\
\hline 12 & Desember & 0,0568 & 0,0366 & 0,0543 & $-0,0162$ & $-0,0140$ & 0,0214 & 0,0093 & $-0,0035$ & 0,0339 \\
\hline
\end{tabular}

Sumber; data olahan, 2019.

\section{Analisis Kinerja Kelompok Saham berdasarkan Model Jensen.}

Model Jensen hanya menerima investasi yang return melebihi expected return atau minimum rate of return. Return yang dimaksud adalah return rata-rata masa lalu, sedangkan minimum rate of return adalah expected return yang dihitung dengan Capital Aset Pricing Model (CAPM). Selisih antara avarage return dengan minimum rate of return disebut sebagai alpha. Jensen ALPHA merupakan sebuah ukuran absolut yang mengestimasikan tingkat pengembalian konstan selama periode investasi dimana memperoleh tingkat Jensen ALPHA pengembalian diatas (dibawah) dari buy-hold strategy dengan risiko sistematik yang sama. Untuk menganalisis model Jensen membutuhkan data seperti avarage return, beta saham, minimum rate, dan risk free rate.

Tabel 3

Kinerja Kelompok Saham berdasarkan Model Jensen saham LQ 45 periode 2010 - 2018.

\begin{tabular}{|c|c|c|c|c|c|c|c|c|c|c|}
\hline \multicolumn{11}{|c|}{ Model Jensen } \\
\hline & Bulan/ Tahun & 2010 & 2011 & 2012 & 2013 & 2014 & 2015 & 2016 & 2017 & 2018 \\
\hline 1 & Januari & & $-0,0272$ & 0,0200 & $-0,0148$ & $-0,0364$ & $-0,0226$ & 0,0191 & $-0,0185$ & 0,0681 \\
\hline 2 & Februari & 0,01707 & $-0,0492$ & 0,0301 & $-0,0336$ & 0,0175 & $-0,0142$ & $-0,0005$ & 0,0123 & $-0,0165$ \\
\hline 3 & Maret & 0,00136 & $-0,0087$ & 0,0426 & $-0,0028$ & 0,0247 & $-0,0174$ & 0,0684 & $-0,0130$ & $-0,0321$ \\
\hline 4 & April & $-0,03383$ & 0,0149 & $-0,0229$ & 0,0103 & 0,0366 & $-0,0136$ & 0,0058 & $-0,0110$ & 0,0256 \\
\hline 5 & Mei & $-0,01407$ & $-0,0002$ & $-0,0073$ & 0,0197 & $-0,0057$ & 0,0280 & $-0,0338$ & $-0,0162$ & $-0,0225$ \\
\hline 6 & Juni & 0,00632 & $-0,0012$ & $-0,0680$ & $-0,0096$ & 0,0041 & $-0,0153$ & 0,0283 & $-0,0044$ & $-0,0407$ \\
\hline 7 & Juli & 0,03199 & $-0,0089$ & 0,0141 & $-0,0879$ & 0,0047 & $-0,0493$ & 0,0708 & 0,0459 & 0,0148 \\
\hline 8 & Agustus & 0,01670 & 0,0024 & $-0,0114$ & 0,0714 & $-0,0067$ & $-0,0528$ & 0,0358 & 0,0249 & 0,3310 \\
\hline 9 & September & 0,00565 & $-0,0169$ & 0,0291 & $-0,0539$ & $-0,0313$ & 0,0593 & $-0,0043$ & $-0,0358$ & $-0,0023$ \\
\hline 10 & Oktober & 0,01818 & 0,0150 & $-0,0646$ & 0,0047 & 0,0072 & 0,0117 & 0,0350 & 0,0361 & $-0,0226$ \\
\hline 11 & November & 0,01933 & 0,0313 & $-0,0158$ & 0,0351 & 0,0025 & $-0,0532$ & 0,0356 & $-0,0520$ & $-0,0467$ \\
\hline 12 & Desember & 0,01672 & 0,0087 & 0,0354 & 0,0077 & $-0,0229$ & $-0,0223$ & $-0,0187$ & $-0,0754$ & 0,0141 \\
\hline
\end{tabular}

Sumber; data olahan, 2019.

\section{Analisis Kinerja Kelompok Saham berdasarkan Model Sortino.}

Tingkat suku bunga Sertifikat Bank Indonesia digunakan sebagai tingkat suku bunga bebas risiko. Besarnya Minimal Acceptable Return (MAR) adalah tingkat suku bunga minimum yang diharapkan sebagai 
Pantun Bukit et al, Analisis Perbedaan Kinerja Saham Perusahaan Berdasarkan Model Sharpe, Treynor, Jensen dan Sortino Pada Kelompok Saham LQ 45 Di Bursa Efek Indonesia Periode 2010 - 2018

return oleh setiap investor dari investasi yang dilakukannya. Return yang berada dibawah MAR maka akan dianggap sebagai return yang tidak menguntungkan atau risiko dan return yang lebih besar dari MAR akan dikatakan sebagai return yang menguntungkan.

Tabel 4

Kinerja kelompok Saham berdasarkan Model Sortino saham LQ 45 periode 2010 - 2018.

\begin{tabular}{|c|c|c|c|c|c|c|c|c|c|c|}
\hline \multicolumn{11}{|c|}{ Model Sortino } \\
\hline & Bulan/ Tahun & 2010 & 2011 & 2012 & 2013 & 2014 & 2015 & 2016 & 2017 & 2018 \\
\hline 1 & Januari & & $-3,2939$ & 1,3266 & 0,4522 & $-0,0268$ & $-0,3157$ & 1,6976 & $-0,7834$ & 2,7323 \\
\hline 2 & Februari & $-0,1926$ & $-1,8151$ & 2,0169 & 1,0895 & 1,7455 & 1,3582 & 1,9723 & 0,8263 & $-0,6361$ \\
\hline 3 & Maret & 2,2943 & 1,6031 & 2,0472 & 0,2900 & 1,5142 & $-0,1340$ & 3,1999 & 0,4218 & $-3,1890$ \\
\hline 4 & April & 0,5398 & 1,2980 & $-0,7498$ & 0,9363 & 1,6266 & $-2,8761$ & $-0,0596$ & 0,1923 & $-0,4058$ \\
\hline 5 & Mei & $-1,7612$ & 0,0547 & $-2,5828$ & 0,0848 & 0,1240 & 1,8867 & $-1,4289$ & $-0,0435$ & $-3,8272$ \\
\hline 6 & Juni & 1,2528 & 0,2769 & $-0,9542$ & $-2,4839$ & 0,0698 & $-2,3092$ & 3,0884 & 0,3952 & $-5,1424$ \\
\hline 7 & Juli & 2,0643 & 1,1735 & 1,8744 & $-5,8668$ & 1,5609 & $-2,3188$ & 3,1457 & 1,3287 & 1,1574 \\
\hline 8 & Agustus & 0,1447 & $-1,8011$ & $-0,9700$ & $-0,1309$ & $-0,1798$ & $-2,9625$ & 6,9347 & 2,1997 & 9,5238 \\
\hline 9 & September & 3,2755 & $-2,5478$ & 2,2314 & $-3,2025$ & $-0,8564$ & $-0,3432$ & 1,0054 & 0,3650 & $-1,3852$ \\
\hline 10 & Oktober & 1,4043 & 3,5786 & $-1,3245$ & 0,7336 & 0,0748 & 2,3459 & 2,4947 & 1,4521 & $-1,3310$ \\
\hline 11 & November & $-0,7410$ & 2,2091 & $-1,3150$ & $-0,6026$ & $-0,2349$ & $-1,7906$ & $-0,8193$ & $-1,6104$ & $-1,3461$ \\
\hline 12 & Desember & 1,4497 & 0,9350 & 1,3857 & $-0,4145$ & $-0,3570$ & 0,5451 & 0,2370 & $-0,0893$ & 0,8657 \\
\hline
\end{tabular}

Sumber; data olahan, 2019.

\section{Perbandingan Kinerja Kelompok Saham berdasarkan Model Sharpe, Treynor, Jensen dan Sortino.}

Kinerja kelompok saham akan diukur dengan menggunakan empat model yang berbeda yaitu Model Sharpe, Treynor, Jensen dan Sortino. Pengukuran kinerja kelompok saham untuk ke empat model yang berbeda tersebut memerlukan data-data berupa return kelompok saham, standar deviasi, return pasar dan risk free rate. Mengingat formulasi dan karakteristik pengukuran kinerja dari masing-masing adalah berbeda, maka nilai model kinerja yang diperoleh dari hasil perhitungan angka model juga berbeda. Masingmasing model kinerja kelompok saham memiliki dasar angka relatif yang tidak dapat dibandingkan secara langsung satu dengan yang lainnya mengingat model pengukurannya adalah berbeda-beda. Dalam penelitian ini akan dicoba menstandarisasi nilai angka model dari ke empat model pengukuran tersebut. Tujuan dari penelitian ini adalah untuk mengetahui apakah ketiga model pengukuran kinerja tersebut adalah berbeda atau tidak ada beda untuk 1 kelompok yang sama, maka terlebih dahulu mencari nilai standar dari masingmasing pengukuran kinerja. Nilai standar akan dihitung dengan menggunakan masing-masing angka relatif dengan model standardized (transformasi Z-score). Z-score adalah cara mengkonversikan nilai data ke dalam skor standardized yang memiliki nilai means (rata-rata) sama dengan 0 (nol) dan standar deviasinya sama dengan 1 (satu).

Tabel 5

Kinerja Saham berdasarkan Nilai Z-Score kelompok saham LQ 45 periode 2010 - 2018.

\begin{tabular}{rrrrr}
\hline \multicolumn{1}{c}{ Periode } & Nilai Z Sharpe & Nilai Z Treynor & Nilai Z Jensen & Nilai Z Sortino \\
\hline Jan-10 & & & & $-0,20762$ \\
Feb-10 & $-0,20762$ & $-0,20762$ & 0,33536 & 0,96370 \\
Mar-10 & 0,96370 & 0,96370 & $-0,01357$ & 0,13733 \\
Apr-10 & 0,13733 & 0,13733 & $-0,79517$ & $-0,94643$ \\
May-10 & $-0,94643$ & $-0,94643$ & $-0,35612$ & 0,47315 \\
Jun-10 & 0,47315 & 0,47315 & 0,09676 & 0,85541 \\
Jul-10 & 0,85541 & 0,85541 & 0,66672 & $-0,04878$ \\
Aug-10 & $-0,04878$ & $-0,04878$ & 0,32728 & 1,42589 \\
Sep-10 & 1,42589 & 1,42589 & 0,08167 & 0,54451 \\
Oct-10 & 0,54451 & 0,54451 & 0,36008 & $-0,46592$ \\
Nov-10 & $-0,46592$ & $-0,46592$ & 0,38559 & 0,56593 \\
Dec-10 & 0,56593 & 0,56593 & 0,32766 & $-1,66838$ \\
Jan-11 & $-1,66838$ & $-1,66838$ & $-0,64787$ & $-0,97182$ \\
Feb-11 & $-0,97182$ & $-0,97182$ & $-1,13676$ & 0,63816 \\
Mar-11 & 0,63816 & 0,63816 & $-0,23649$ & 0,49448 \\
Apr-11 & 0,49448 & 0,49448 & 0,28791 & $-0,09113$ \\
May-11 & $-0,09113$ & $-0,09113$ & $-0,04804$ & 0,01353 \\
Jun-11 & 0,01353 & 0,01353 & $-0,07049$ &
\end{tabular}


Pantun Bukit et al, Analisis Perbedaan Kinerja Saham Perusahaan Berdasarkan Model Sharpe, Treynor, Jensen dan Sortino Pada Kelompok Saham LQ 45 Di Bursa Efek Indonesia Periode 2010 - 2018

\begin{tabular}{|c|c|c|c|c|}
\hline Jul-11 & 0,43584 & 0,43584 & $-0,24082$ & 0,43584 \\
\hline Aug-11 & $-0,96525$ & $-0,96525$ & 0,00866 & $-0,96525$ \\
\hline Sep-11 & $-1,31695$ & $-1,31695$ & $-0,41989$ & $-1,31695$ \\
\hline Oct-11 & 1,56864 & 1,56864 & 0,28879 & 1,56864 \\
\hline Nov-11 & 0,92360 & 0,92360 & 0,65184 & 0,92360 \\
\hline Dec-11 & 0,32347 & 0,32347 & 0,15000 & 0,32347 \\
\hline Jan-12 & 0,50794 & 0,50794 & 0,40093 & 0,50794 \\
\hline Feb-12 & 0,83306 & 0,83306 & 0,62407 & 0,83306 \\
\hline Mar-12 & 0,84735 & 0,84735 & 0,90209 & 0,84735 \\
\hline Apr-12 & $-0,47007$ & $-0,47007$ & $-0,55152$ & $-0,47007$ \\
\hline May-12 & $-1,33342$ & $-1,33342$ & $-0,20574$ & $-1,33342$ \\
\hline Jun-12 & $-0,56635$ & $-0,56635$ & $-1,55339$ & $-0,56635$ \\
\hline Jul-12 & 0,76596 & 0,76596 & 0,27037 & 0,76596 \\
\hline Aug-12 & $-0,57379$ & $-0,57379$ & $-0,29670$ & $-0,57379$ \\
\hline Sep-12 & 0,93409 & 0,93409 & 0,60296 & 0,93409 \\
\hline Oct-12 & $-0,74077$ & $-0,74077$ & $-1,47801$ & $-0,74077$ \\
\hline Nov-12 & $-0,73631$ & $-0,73631$ & $-0,39448$ & $-0,73631$ \\
\hline Dec-12 & 0,53578 & 0,53578 & 0,74301 & 0,53578 \\
\hline Jan-13 & 0,09608 & 0,09608 & $-0,37247$ & 0,09608 \\
\hline Feb-13 & 0,39627 & 0,39627 & $-0,78894$ & 0,39627 \\
\hline Mar-13 & 0,01970 & 0,01970 & $-0,10494$ & 0,01970 \\
\hline Apr-13 & 0,32412 & 0,32412 & 0,18493 & 0,32412 \\
\hline May-13 & $-0,07699$ & $-0,07699$ & 0,39412 & $-0,07699$ \\
\hline Jun-13 & $-1,28686$ & $-1,28686$ & $-0,25588$ & $-1,28686$ \\
\hline Jul-13 & $-2,88024$ & $-2,88024$ & $-1,99550$ & $-2,88024$ \\
\hline Aug-13 & $-0,17857$ & $-0,17857$ & 1,54247 & $-0,17857$ \\
\hline Sep-13 & $-1,62531$ & $-1,62531$ & $-1,24157$ & $-1,62531$ \\
\hline Oct-13 & 0,22864 & 0,22864 & 0,06010 & 0,22864 \\
\hline Nov-13 & $-0,40076$ & $-0,40076$ & 0,73514 & $-0,40076$ \\
\hline Dec-13 & $-0,31212$ & $-0,31212$ & 0,12798 & $-0,31212$ \\
\hline Jan-14 & $-0,12955$ & $-0,12955$ & $-0,85134$ & $-0,12955$ \\
\hline Feb-14 & 0,70524 & 0,70524 & 0,34596 & 0,70524 \\
\hline Mar-14 & 0,59630 & 0,59630 & 0,50456 & 0,59630 \\
\hline Apr-14 & 0,64923 & 0,64923 & 0,76930 & 0,64923 \\
\hline May-14 & $-0,05850$ & $-0,05850$ & $-0,17021$ & $-0,05850$ \\
\hline Jun-14 & $-0,08405$ & $-0,08405$ & 0,04808 & $-0,08405$ \\
\hline Jul-14 & 0,61827 & 0,61827 & 0,06041 & 0,61827 \\
\hline Aug-14 & $-0,20161$ & $-0,20161$ & $-0,19169$ & $-0,20161$ \\
\hline Sep-14 & $-0,52027$ & $-0,52027$ & $-0,73977$ & $-0,52027$ \\
\hline Oct-14 & $-0,08168$ & $-0,08168$ & 0,11543 & $-0,08168$ \\
\hline Nov-14 & $-0,22754$ & $-0,22754$ & 0,01253 & $-0,22754$ \\
\hline Dec-14 & $-0,28505$ & $-0,28505$ & $-0,55286$ & $-0,28505$ \\
\hline Jan-15 & $-0,26560$ & $-0,26560$ & $-0,54464$ & $-0,26560$ \\
\hline Feb-15 & 0,52282 & 0,52282 & $-0,35925$ & 0,52282 \\
\hline Mar-15 & $-0,18003$ & $-0,18003$ & $-0,43087$ & $-0,18003$ \\
\hline Apr-15 & $-1,47157$ & $-1,47157$ & $-0,34641$ & $-1,47157$ \\
\hline May-15 & 0,77175 & 0,77175 & 0,57919 & 0,77175 \\
\hline Jun-15 & $-1,20455$ & $-1,20455$ & $-0,38410$ & $-1,20455$ \\
\hline Jul-15 & $-1,20907$ & $-1,20907$ & $-1,13891$ & $-1,20907$ \\
\hline Aug-15 & $-1,51226$ & $-1,51226$ & $-1,21656$ & $-1,51226$ \\
\hline Sep-15 & $-0,27854$ & $-0,27854$ & 1,27381 & $-0,27854$ \\
\hline Oct- 15 & 0,98802 & 0,98802 & 0,21715 & 0,98802 \\
\hline Nov-15 & $-0,96030$ & $-0,96030$ & $-1,22530$ & $-0,96030$ \\
\hline Dec-15 & 0,13985 & 0,13985 & $-0,53899$ & 0,13985 \\
\hline Jan-16 & 0,68266 & 0,68266 & 0,37970 & 0,68266 \\
\hline Feb-16 & 0,81208 & 0,81208 & $-0,05554$ & 0,81208 \\
\hline Mar-16 & 1,39028 & 1,39028 & 1,47479 & 1,39028 \\
\hline Apr-16 & $-0,14496$ & $-0,14496$ & 0,08438 & $-0,14496$ \\
\hline May-16 & $-0,78992$ & $-0,78992$ & $-0,79380$ & $-0,78992$ \\
\hline Jun-16 & 1,33774 & 1,33774 & 0,58460 & 1,33774 \\
\hline Jul-16 & 1,36476 & 1,36476 & 1,52962 & 1,36476 \\
\hline Aug-16 & 3,14942 & 3,14942 & 0,75119 & 3,14942 \\
\hline
\end{tabular}


Pantun Bukit et al, Analisis Perbedaan Kinerja Saham Perusahaan Berdasarkan Model Sharpe, Treynor, Jensen dan Sortino Pada Kelompok Saham LQ 45 Di Bursa Efek Indonesia Periode 2010 - 2018

\begin{tabular}{|c|c|c|c|c|}
\hline Sep-16 & 0,35666 & 0,35666 & $-0,13971$ & 0,35666 \\
\hline Oct-16 & 1,05810 & 1,05810 & 0,73307 & 1,05810 \\
\hline Nov-16 & $-0,50282$ & $-0,50282$ & 0,74802 & $-0,50282$ \\
\hline Dec-16 & $-0,00527$ & $-0,00527$ & $-0,45827$ & $-0,00527$ \\
\hline Jan-17 & $-0,48588$ & $-0,48588$ & $-0,45520$ & $-0,48588$ \\
\hline Feb-17 & 0,27228 & 0,27228 & 0,22868 & 0,27228 \\
\hline Mar-17 & 0,08175 & 0,08175 & $-0,33247$ & 0,08175 \\
\hline Apr-17 & $-0,02632$ & $-0,02632$ & $-0,28782$ & $-0,02632$ \\
\hline May-17 & $-0,13738$ & $-0,13738$ & $-0,40459$ & $-0,13738$ \\
\hline Jun-17 & 0,06925 & 0,06925 & $-0,14103$ & 0,06925 \\
\hline Jul-17 & 0,50891 & 0,50891 & 0,97571 & 0,50891 \\
\hline Aug-17 & 0,91915 & 0,91915 & 0,50947 & 0,91915 \\
\hline Sep-17 & 0,05499 & 0,05499 & $-0,83863$ & 0,05499 \\
\hline Oct-17 & 0,56703 & 0,56703 & 0,75902 & 0,56703 \\
\hline Nov-17 & $-0,87544$ & $-0,87544$ & $-1,19787$ & $-0,87544$ \\
\hline Dec-17 & $-0,15898$ & $-0,15898$ & $-1,71737$ & $-0,15898$ \\
\hline Jan-18 & 1,17001 & 1,17001 & 1,46879 & 1,17001 \\
\hline Feb-18 & $-0,41650$ & $-0,41650$ & $-0,40926$ & $-0,41650$ \\
\hline Mar-18 & $-1,61895$ & $-1,61895$ & $-0,75713$ & $-1,61895$ \\
\hline Apr-18 & $-0,30804$ & $-0,30804$ & 0,52578 & $-0,30804$ \\
\hline May-18 & $-1,91957$ & $-1,91957$ & $-0,54305$ & $-1,91957$ \\
\hline Jun-18 & $-2,53901$ & $-2,53901$ & $-0,94855$ & $-2,53901$ \\
\hline Jul-18 & 0,42823 & 0,42823 & 0,28457 & 0,42823 \\
\hline Aug-18 & 4,36889 & 4,36889 & 7,30738 & 4,36889 \\
\hline Sep-18 & $-0,76934$ & $-0,76934$ & $-0,09491$ & $-0,76934$ \\
\hline Oct-18 & $-0,74383$ & $-0,74383$ & $-0,54512$ & $-0,74383$ \\
\hline Nov-18 & $-0,75092$ & $-0,75092$ & $-1,08118$ & $-0,75092$ \\
\hline Dec-18 & 0,29085 & 0,29085 & 0,26907 & 0,29085 \\
\hline
\end{tabular}

Sumber; data olahan ,2019

Pengukuran kinerja kelompok dengan model Sharpe, Treynor, Jensen dan Sortino akan memiliki karakteristik angka model yang berbeda satu sama lain sehingga tidak dapat dibandingkan satu dengan lainnya secara langsung sehingga diperlukan standarisasi ukuran kinerja yang dapat digunakan untuk membandingkan pengukuran kinerja kelompok yang menggunakan model Sharpe, model Treynor, model Jensen dan model Sortino yaitu dengan transformasi Z-score (standardized). Nilai-nilai Z-score tersebut akan menunjukkan jangkauan dari masing-masing ukuran kinerja yang dihitung dengan model yang berbeda. Setelah masing-masing periode kinerja sudah memiliki rangking tertentu dari pengukuran kinerja kelompok dengan model yang berbeda, maka langkah selanjutnya adalah menguji apakah kinerja kelompok pada tiap-tiap periode akan memiliki rangking yang sama jika diukur dengan menggunakan empat model yang berbeda. Karena data yang digunakan selanjutnya adalah berupa rangking, maka pengujian dengan statistik non parametrik akan lebih tepat digunakan. Pengujian ini dilakukan dengan membandingkan individu/sampel yang sama/kasus yang sama dengan kondisi yang berbeda. Setiap sampel diukur dengan semua kondisi, maka untuk desain seperti ini disebut dengan One way analysis of variance by rank dengan model yang digunakan adalah uji Kruskal Wallish.

Tabel 6

Npar Tests

\begin{tabular}{|c|c|c|c|c|c|}
\hline & $\mathrm{N}$ & Mean & Std. Deviation & Minimum & Maximum \\
\hline Model Treynor & 107 &, 000000 & 1,0000000 & $-2,8802$ & 4,3689 \\
\hline Model Jensen & 107 &, 000000 & 1,0000000 & $-1,9955$ & 7,3074 \\
\hline Model Sortino & 107 &, 000000 & 1,0000000 & $-2,8802$ & 4,3689 \\
\hline Model Sharpe & 107 & ,000000 & 1,0000000 & $-2,8802$ & 4,3689 \\
\hline
\end{tabular}

Sumber; Hasil olahan, 2019

Tabel 6 diatas menunjukkan jumlah sampel dalam penelitian ini sebanyak 107 dengan nilai mean 0 dan standar deviasi sebesar 1. Nilai minimum yang dihasilkan yaitu sebesar -2,8802 dihasilkan dari pengukuran indeks Sharpe, Treynor dan Sortino sedangkan indeks Jensen sebesar -1,9955., adapun nilai maksimum sebesar 4,3689 dari pengukuran indeks Sharpe, Treynor dan Sortino, sedangkan dari pengukuran 
Pantun Bukit et al, Analisis Perbedaan Kinerja Saham Perusahaan Berdasarkan Model Sharpe, Treynor, Jensen dan Sortino Pada Kelompok Saham LQ 45 Di Bursa Efek Indonesia Periode 2010 - 2018

indeks Jensen nilai maksimum sebesar 7,3074. Hasil pengujian secara simultan dengan uji Kruskal Wallish Z-score Indeks Sharpe, Treynor, Jensen dan Sortino dapat dilihat pada tabel berikut:

Tabel 7

Hasil Uji Kruskal Wallish Z-score Indeks Sharpe, Treynor, Jensen dan Sortino.

\begin{tabular}{|c|c|c|c|}
\hline & Model Treynor & Model Jensen & Model Sortino \\
\hline Chi-Square & 4,267 & 2,438 & 4,267 \\
\hline df & 2 & 2 & 2 \\
\hline Asymp. Sig. & ,118 & ,296 &, 118 \\
\hline
\end{tabular}

Sumber; Hasil olahan, 2019

Tabel 7 merupakan hasil pengujian dengan uji Kruskal Wallish pada ke empat model didapatkan nilai Chi-Square atau $\chi^{2}=4,267$, dengan probabilitas 0,118. Maka dapat diketahui bahwa probabilitas pengujian $>0,05$ dan $\chi^{2}$ hitung $<\chi^{2}$ tabel sebesar 5,32. Hasil ini menunjukkan bahwa tidak adanya perbedaan yang signifikan antara pengujian dengan model Sharpe, Treynor, Jensen dan Sortino. Dengan demikian hipotesis nihil (H0) dalam penelitian ini diterima.

Keputusan pengujian:

- Jika probabilitas pengujian $<0,05$ maka keempat model pengukuran kinerja kelompok saham adalah berbeda.

- Jika probabilitas pengujian > 0,05 maka keempat model pengukuran kinerja kelompok saham adalah tidak memiliki perbedaan yang bermakna.

Dengan demikian nilai probabilitas sebesar 0,118 dan 0,296>0,05 sehingga dapat dikatakan pengukuran kinerja kelompok saham tidak memiliki perbedaan yang bermakna. Dengan demikian hipotesis nihil (H0) dalam penelitian ini diterima dan hipotesis H1 ditolak. Tidak adanya perbedaan antara ke empat model pengukuran kinerja tersebut menunjukkan bahwa pengukuran kinerja dengan menggunakan model Sharpe, Treynor, Jensen dan Sortino tidak menghasilkan adanya perbedaan yang signifikan atas hasil kinerja kelompok saham dalam suatu periode. Pengujian lain dengan membandingkan antar treatment perhitungan kinerja kelompok saham sebagai kelanjutan dari uji Kruskal Wallish didapatkan tidak adanya perbedaan yang bermakna antara masing-masing treatment yaitu dengan melihat selisih ke empat mean rank seperti terlihat dalam lampiran perhitungan. Dengan melihat selisih ke empat mean rank maka model Sharpe, Treynor, dan Sortino adalah yang paling menunjukkan konsistensi terhadap ketidakbedaan antar ke empat pengukuran, karena Jensen memiliki selisih mean rank yang paling rendah terhadap Sharpe, Treynor dan Sortino. Selisih antar mean rank ini juga menunjukkan dalam pengukuran kinerja kelompok saham relatif konsisten untuk mengukur kinerja kelompok saham terutama bila digunakan pada pengukuran kinerja kelompok saham di Bursa Efek Indonesia.

Penelitian ini, hampir sama dengan penelitian yang dilakukan oleh Sulistyorini (2009), dalam penelitiannya tersebut melakukan analisis kinerja kelompok saham saham LQ 45 menggunakan model Sharpe, Treynor dan Jensen. Hasil penelitian menunjukkan perhitungan kinerja kelompok saham saham dalam penelitian menggunakan uji beda dengan menggunakan One Way of Variance by Rank dengan Kruskal-Wallish, yang sebelumnya dilakukan transformasi data untuk menstandarkan ukuran kinerja tersebut yaitu dengan menggunakan transformasi Z-score (standardized). Dengan melihat selisih ke tiga mean rank maka model Treynor adalah yang paling menunjukkan konsistensi terhadap ketidakbedaan antar ketiga pengukuran, karena Treynor memiliki selisih mean rank yang paling rendah terhadap Sharpe maupun Jensen. Perbedaan dengan penelitian ini, dimana dengan melihat selisih ke empat mean rank maka model Jensen adalah yang paling menunjukkan konsistensi terhadap ketidakbedaan diantara empat model pengukuran, karena model Jensen memiliki selisih mean rank yang paling rendah terhadap model Sharpe, Treynor maupun Sortino.

\section{SIMPULAN}

Penelitian ini diperoleh berdasarkan analisis terhadap hasil penelitian telah dijelaskan pada bab sebelumnya, maka dapat ditarik kesimpulan yaitu: Hasil pengujian perbedaan pengukuran kinerja kelompok saham menggunakan model Sharpe, Treynor dan Sortino dengan uji Kruskal Wallis menunjukkan nilai ChiSquare atau $\chi^{2}=4,267$ sedangkan model Jensen sebesar 2,438 dengan probabilitas pengujian > 0,05 dimana $\chi^{2}$ hitung $<\chi^{2}$ tabel $(5,32)$ hal tersebut menggambarkan tidak adanya perbedaan yang signifikan dalam 
Pantun Bukit et al, Analisis Perbedaan Kinerja Saham Perusahaan Berdasarkan Model Sharpe, Treynor, Jensen dan Sortino Pada Kelompok Saham LQ 45 Di Bursa Efek Indonesia Periode 2010 - 2018

mengukur kinerja dengan menggunakan model Sharpe, Treynor, Jensen dan Sortino. Sedangkan uji antar treatment terhadap ke empat model tersebut juga menunjukkan tidak adanya perbedaan yang signifikan diantara ke empat model. Pengukuran selisih mean rank maka model Jensen menunjukkan nilai yang sedikit lebih tinggi dari konsistensi terhadap ketidakbedaan antar ke empat model pengukuran.

\section{DAFTAR PUSTAKA}

Ataie, Younes,. 2012. Evaluation Performance of 50 Top Companies Listed in Tehran Stock Exchange by Sortino, EROV, and M3. International Journal of Economics and Finance.

Bart, J, 1992, International Diversification: Part I - Risk Reduction \& Return Enhancement, Canadian Shareower 5: 10-11

Bawazier, Said dan Jati Pingkir Sitanggang, 1994, Memilih Saham untuk Portofolio Optimal, Usahawan XI h.34-40

Elton, E.J, and Grubber, 1977, Risk Reduction and Portofolio Size: An Analytical Solution, Journal of Business, Vol 50 October p.415-437.

Elton, E.J, and Grubber, 1995, Modern Portfolio Theory and Invesment Analysis 5th ed, John Wiley \& Sons, New York.

Fabbozi, Frank J, 1999, Manajemen investasi, Salemba Empat, Jakarta.

Fadlu, Fitri, 2002, Uji Konsistensi antara Sharpe, Jensen, dan Treynor Indeks sebagai Alat Ukur Kinerja Portofolio (Studi Empiris pada BEJ Periode Juli 1994 sampai Juli 1997), Tesis Universitas Gajah Mada (tidak dipublikasikan).

Husnan, Suad, 1998, Manajemen Keuangan : Teori dan Penerapan : Edisi Ke enam, BPFE, Yogyakarta. Husnan, Suad, 2003, Dasar-Dasar Teori Portofolio dan Analisis Sekuritas, UPP AMP YKPN, Yogyakarta

Jobson and Korkie, 1981, The Trouble with Performance Measuremen Comment, Journal of Portofolio Management, Winter.

Jogiyanto, 2003, Analisis Investasi dan Teori Portofolio, Gajah Mada Press, Yogyakarta.

Jones, Charles P., 2000, Investment Analysis and Management 7th ed, USA: John Wiley \& Sons, Inc.

Kurniawan, Purnama, 2001, Analisis Kinerja Portafolio Saham Berdasarkan Model Indeks Tunggal dan Rasionalitas Investor Saham (Studi Kasus terhadap Kelompok Saham LQ 45 dan 20 Top Gainers), Tesis Program Pasca Sarjana Magíster Manajemen Universitas Diponegoro (tidak dipublikasikan).

Manurung, Adler Haymans, 2000, Mengukur Kinerja Portofolio, Usahawan, No 11 Nopember XXIX,h 4146.

Markowitz, Harry M, 1999,The Early History of Portofolio Theory: 1600-1960, Financial Analysis Journal, July-August p.5-16.

Martalena dan Maya Malinda. 2011. Pengantar Pasar Modal. Yogyakarta: Andi.

Mudasetia, Hamid, 1995, Analisis Penentuan Saham yang akan dibeli, Suatu Tinjauan Umum, Kajian Bisnis, No. 6 September.

Reilly, FR and KC Brown, 1997, Investment Analysis \& Portfolio Management, Thomson South-Western.

Robert Ang, 1997, Pasar Modal Indonesia, Mediasoft, Indonesia.

Sartono, R Agus dan Sri Zulaihati, 1998, Rasionalitas Investor Terhadap Pemilihan Saham dan Penentuan Portofolio Optimal dengan Model Indeks Tunggal di BEJ, Kelola, No.17/VII/1998.

Sartono, R Agus, 2001, Manajemen Keuangan: Teori dan Aplikasi, Edisi 4 BPFE, Jogjakarta.

Samsul, Mohammad, 2006, Pasar Modal Dan Manajemen Portofolio, Erlangga, Jakarta.

Sharpe, William F, 1995, Risk, Market Sensitivy and Diversification, Financial Analysist Journal, JanuariFebruari, pp. 84-88.

Simforianus., Yanthi Hutagaol., 2008 Analisis Kinerja Reksa Dana Saham dengan Metode Raw Return, Sharpe, Treynor, Jensen dan Sortino. Journal of Applied Finance and Accounting Vol. 1.

Solnik, Bruno, H, 1995, Why not Diversify Internationally rather than Domestically, Financial Analysist Journal, Januari-Februari, pp.89-94.

Sortino, Frank A., Lee N Price. 1994, Performance Measurement in a Downside Risk Framework. The Journal of Investing Fall.

Statman, Meir, 1987, How Many Stocks Make a Diversified Portofolio, Journal of Financial and Quantitative Analysis, Vol.22 no.2 September p.353-363. 
Sumariyah, 1997, Teori Portofolio: Pengantar Pengetahuan Pasar Modal, UPP AMPN YKPN, Yogyakarta. Tandelilin, Eduardus, 2001, Analisis Investasi dan Manajemen Portofolio, BPFE, Yogyakarta.

Tehrani, Reza., Hamed Ahmadinia., Amaneh Hasbaei, 2011, Analyzing Performance of Investment Companies Listed in the Tehran Stock Exchange by Selected Ratios and Measures. African Journal of Business Management Vol. 5 (17).

Yuswan Suryawan, 2003, Evaluasi Kinerja Portofolio Saham di BEJ (Studi Empiris Saham-Saham LQ 45), Tesis Program Pasca Sarjana Magíster Manajemen Universitas Diponegoro (tidak dipublikasikan )

Zubir, Zalmi. 2011, Manajemen Portofolio: Penerapannya dalam Investasi Saham. Salemba Empat: Jakarta.. 